\title{
A resource-based approach to the Booz Allen and Hamilton methodology: exploring new directions for practice
}

\author{
A. Larsson* and M. Bergfors \\ Luleå University of Technology, \\ Luleå, Sweden \\ E-mail: andreas.larsson@ies.luth.se \\ E-mail: markus.bergfors@ltu.se \\ ${ }^{*}$ Corresponding author
}

\begin{abstract}
Two major streams in strategy research are the strategic positioning approach and the resource-based approach to strategy formulation. However, resources and products can be considered as two sides of the same coin, implying one view is not necessarily superior to the other. In this paper, the well-known Booz Allen and Hamilton methodology for innovation strategy formulation, originally based on a strategic positioning approach to strategy, is revisited with a resource-based approach to strategy. Eight propositions are investigated through case studies conducted in two multinational corporations. It shows that both the established methodology and the revisited methodology are used in multinational corporations today. Case analyses indicate that there are three contingencies that shape the structure of innovation strategy formulation processes - level of diversification; characteristics of industry boundaries, customers and competitors and Role and organisation of R\&D. In the light of these results new directions for practice and managerial implications are explored.
\end{abstract}

Keywords: innovation strategy; strategic planning; resource-based view; industrial organization; management tool.

Reference to this paper should be made as follows: Larsson, A. and Bergfors, M. (2007) 'A resource-based approach to the Booz Allen and Hamilton methodology: exploring new directions for practice', Int. J. Intelligent Enterprise, Vol. 1, No. 1, pp.3-22.

Biographical notes: Andreas Larsson is affiliated with the Centre for Management of Innovation and Technology in Process Industry at Luleå University of Technology, Sweden and Nihon University Graduate School of Business, Japan. His research interests include technology management in process industry with emphasis on the process of innovation strategy formulation and technology strategic planning.

Markus Bergfors is affiliated with the Centre for Management of Innovation and Technology in Process Industry. His research interest is in innovation and organisation design. Current projects include organising $R \& D$ in process industries. 


\section{Introduction}

In the 1980s, strategic management scholars showed increased attention to the fact that innovation can be considered a powerful competitive weapon. Most of the early strategy research on innovation was based on a positioning approach to strategy whose principles can be traced back to industrial organisation in economics, developed by Mason (1939, $1949)$ and Bain $(1956,1968)$. The positioning approach focuses on market structure and positioning within industries, to help find the most favourable product-market and the most favourable position in that particular product-market.

In the early days of research on innovation strategy formulation, several methodologies were developed in the spirit of the positioning approach. However, recent research has argued that as business boundaries are blurring and evolving customers and competitors are more often unidentifiable, existing conceptions of product-markets are not a good basis for understanding competitiveness (D'Aveni, 1995; De Toni and Tonchia, 2002; Prahalad and Hamel 1990) and as a result, it is commonly argued that innovation strategy formulation should originate from internal resources rather than positions in product markets (Chiesa, 2001; Chiesa and Manzini, 1996). Unfortunately, in this stream of research, known as the resource-based approach to strategy, less attention has been paid to the fact that practitioners are in need of management tools and techniques that can help them structure problems and make decisions.

For that reason, the goal of this paper is to introduce a new management tool derived from the resource-based view and to explore how management tools actually are used today. In order to do this, a widely used tool, the Booz Allen and Hamilton methodology (Pappas, 1984) is revisited with a resource-based approach to strategy formulation (Larsson and Bergfors, 2006). Eight propositions are investigated in two multinational corporations. This paper contributes to innovation management and strategic management knowledge in three areas. Firstly, it provides descriptive data on innovation strategy formulation of multinational corporations. Secondly, it indicates that corporations of today either focus on positions or resources in the work-process of innovation strategy formulation. Finally, it sheds light upon key aspects that help explain why corporations choose to focus on either positions or resources in the work-process of innovation strategy formulation.

\section{Theoretical background}

\subsection{Positioning approach}

The contemporary positioning approach to strategy is very much influenced by the work of Porter (1980, 1985). To Porter, the ultimate goal of the firm is to find an attractive relative position, within an attractive product-market, in an attractive industry. Either this position can arise from the selection of a cost base lower than the competition or from the firm's ability to differentiate its offerings and command a premium price that exceeds the accumulation of the extra costs. According to Porter, industry structure affects the sustainability of firm performance, whereas positioning of end products reflects the firm's ability to establish advantage over its competitors.

Corporations sell their variety of end products in various product-markets. A product-market is identified by a generic class of products (Sissors, 1966). Sissors points out that product-markets are "referring to individuals who in the past have 
purchased a given class of products... the assumption is usually made that those persons who will buy a product in the future will be very much like those who have purchased it in the past" (1966, p.17).

In addition, two fundamental assumptions are made in the positioning approach. Firstly, it is assumed that the product-market is distinct (there is a clarity of customers and competitors). Secondly, it is assumed that competition occurs at the level of product lines and/or businesses.

\subsection{Resource-based approach}

The principles of a resource-based approach to strategy can be traced back to Edith Penrose's work The Theory of the Growth of the Firm (Penrose, 1959). Penrose argues

1 that corporations will grow in the direction of their slowly changing resources and

2 that the resources in the short run are both a limit to and a catalyst for growth.

Barney defines resources as all assets, capabilities, organisational processes, firm attributes, information, knowledge, etc. controlled by a firm that enable the firm to conceive of and implement strategies that improve its efficiency and effectiveness (Barney, 1991). Resources can be classified into tangible and intangible resources (Haanes and Löwendahl, 1997). ${ }^{1}$

Corporations can either specify activities in product-markets and from these infer the minimum necessary resource commitments, or by specifying a resource profile for a firm find the optimal product-market activities (Wernerfelt, 1984). From this logic, (1984) Wernerfelt concludes that resources and products are two sides of the same coin as the corporation could be seen as a portfolio of resources as well as a portfolio of products. Furthermore, he argues that it is possible to identify a corporation's optimal product-market configuration by specifying its resource profile.

\section{The Booz Allen and Hamilton methodology}

The Booz Allen and Hamilton methodology was presented by Pappas (1984) at a time when the concept of 'technology strategy' was new to most corporations (Little, 1984). However, as 'technology strategy' evolved into a broader concept of 'innovation management' (Miller and Morris, 1998; Roussel et al., 1991) Pappas' ideas have continued to be applied by practitioners and academics as well as being taught at business schools.

The methodology aims at developing an innovation strategy by analysing a corporation's technology vis-à-vis its business portfolio. It consists of a four-step procedure that is carried out in the following sequential order:

1 technology situation assessment

2 technology portfolio development

3 technology and business strategy integration and

4 setting technology investment priorities. 


\subsection{Step 1: Technology situation assessment}

The first step of the methodology consists of internal and external scanning. Pappas states that the internal scan should focus on product and business levels, while the external scan should focus on technology investment patterns of competitors in each product-market. Consequently, Pappas suggests that corporations should:

1 scan technology on the product and business level of the corporation (internally) and

2 scan the investment pattern of competitors in specific product-markets (externally).

\subsubsection{Reply from a resource-based view to (1) and (2)}

While resources form the basis for corporations ability to compete (Barney, 1991; Knott, 2003; Rumelt, 1984; Wernerfelt, 1984), simply looking at resources from the perspective of single products and single-product funding may inhibit the creation of long-term consistency and focus (Meyer and Utterback, 1993). This notion is based on the view that a bundle of intangible resources have the potential to bring access and competitive advantages to multiple product markets through end-products, is referred to as 'core products' (Prahalad and Hamel, 1990). This implies that internally, corporations should focus their scan on corporate-wide compositions of intangible resources that may form basis for end-products in the assessment of their technology situation.

Corporations should scan the competitive environment based on competitors' resource positions (Bettis and Hitt, 1995; Grant, 1991) and especially those competitors' core products (Prahalad and Hamel, 1990), rather than on product market positions and investment patterns of immediate competitors. This approach may help to avoid the consequence of emerging technological discontinuities, as these can be competence-destroying for industry incumbents (Anderson and Tushman, 1990; Collis, 1994; Tushman and Anderson, 1986; Utterback, 1994). Besides, Leonard-Barton stresses that corporation's should "scan broadly, because technological knowledge comes from a very diverse set of sources, the wider managers cast the net, the more likely a prize will be caught within" (Leonard-Barton, 1995, p.156). If corporations focus too strictly on competitors only within their product-market, they will risk missing the development of new ways of satisfying customer needs.

Proposition 1: In the process of innovation strategy formulation, it is more appropriate to base the internal scan on intangible resources than basing it with respect to each specific product or each specific business segment.

Proposition 2: In the process of innovation strategy formulation, it is more appropriate to focus the external scan on corporations with similarities in intangible resources than focusing on investment patterns of immediate competitors in each product market.

A resource-based approach to technology situation assessment might imply the following for the Booz Allen and Hamilton methodology:

(1) scan for resources on a corporate-wide level (internal) and

(2) scan the environment for corporations with the same intangible resources (external). 


\subsection{Step 2: Technology portfolio development}

The second step is technology portfolio development. Pappas claims that the technology portfolio is a tool that can be used to 'identify and systematically analyse key corporate technology alternatives and to set technology priorities' $(1984$, p.32) and he proposes that the technology portfolio should be evaluated with respect to each business segment. In summary, Pappas suggests that corporations should:

(3) evaluate technology importance with respect to each given business segment and

(4) evaluate relative technology position with respect to each given business segment.

\subsubsection{Reply from a resource-based view to (3) and (4)}

As a business segment is a collection of product-markets within an industry (Sissors, 1966), the evaluation of technologies with respect to business segments gives rise to islands of knowledge about the technology requirements of the corporation only with respect to these product-markets, but no knowledge about the distance between the islands (i.e. possibilities for synergies and economies of scale). Therefore, Prahalad and Hamel (1990) suggest that core products are a more stable basis for technology portfolio evaluation than developing a technology portfolio on the premises of technology importance and relative technology position in each single business segment.

Proposition 3: In the process of innovation strategy formulation it is more appropriate to evaluate the technology importance with respect to core products than to evaluate technology importance with respect to each given business segment.

Proposition 4: In the process of innovation strategy formulation, it is more appropriate to evaluate the relative technology position in respect to core products rather than to evaluate relative technology position with respect to each identified business segment.

A resource-based approach to technology portfolio development might imply the following for the Booz Allen and Hamilton methodology:

1 evaluate the importance of intangible resources in core products and

2 evaluate relative resource position in respect to core products.

\subsection{Step 3: Technology and corporate strategy integration}

The third step asserts that the technology portfolio should be aligned with the business portfolio in order to gain advantage in technology-related businesses. In Pappas' example, the business portfolio measures a corporation's products in terms of positions in product-markets and according to Pappas, selection of positions in each product-market should be based on two dimensions: business segment attractiveness, which is the search for favourable product-markets and the corporation's potential competitive position in the particular business segment, which signifies the ability to capitalise on each specific product-market (Pappas, 1984). Pappas suggests that corporations should: 
(5) Align technology portfolio with current business portfolio on specific business and specific product levels.

\subsubsection{Reply from a resource-based view to (5)}

There is an inherent risk in basing business attractiveness on positions in product-markets, as these are based on the buying behaviour of previous customers (Prahalad, 1998; Prahalad and Hamel, 1990). Observed to FOUND that corporations who become too focused on existing customers and scanning existing markets may fail to launch the next generation of products that are based on new technology and that they, risk being held captives by their customers (Christensen, 1997). Furthermore, it is argued that there is an inherent current customers technology may influence future strategy; just as current strategy can also influence future technology (Itami and Numagami, 1992). Itami and Numagami trace the origin of this research back to Penrose (1959) and Chandler (1962), where path dependency among accumulated resources from past business activities becomes the driving force for further potential for growth.

Proposition 5: In the process of innovation strategy formulation, the relationship between technology and business strategy should be characterised by a dynamic relationship rather than a static relationship.

A resource-based approach to technology and business strategy integration might the following for the Booz Allen and Hamilton methodology:

1 A dynamic alignment between technology portfolio and business portfolio focused on specific intangible resources and core products.

\subsection{Step 4: Setting technology investment priorities}

The fourth step concerns the setting of technology investment priorities. In short, Pappas suggests that corporations should:

(6) identify and commit investments to specific businesses and

(7) identify and commit investments to specific products.

\subsubsection{Reply from a resource-based view to (6) and (7)}

It is suggested that the competitive environment demands more flexibility than ever before (Bettis and Hitt, 1995; Danneels, 2002; D'Aveni, 1995; Sanchez, 1995) but some degree of stability in strategy formulation may be gained by focusing on resources rather than positions in specific product-markets and specific businesses. This is due to the stability that resources provide compared to product-markets. While the resources that a corporation possesses are slow to change (Penrose, 1959) and path dependant (Helfat, 1994) and technological discontinuities may appear seemingly out of nowhere (Anderson and Tushman, 1990; Tushman and Anderson, 1986; Utterback, 1994), it becomes increasingly important to focus investments on intangible resources and guard against technological discontinuities rather than investing for temporary positions in product-markets. Markides and Williamson note that also 'simply exploiting existing strategic assets will not create long-term competitive advantage' (Markides and Williamson, 1994, p.164). 
Proposition 6: In the process of innovation strategy formulation, it is appropriate to commit investments to ensure that requirements for specific intangible resources are met rather than to ensure that investments are committed to each specific business.

Proposition 7: In the process of innovation strategy formulation, it is appropriate to commit investments to ensure that requirements for specific core products are met rather than to ensure that investments are committed to specific products.

A resource-based approach to setting technology investment priorities might imply the following for the revisited Booz Allen and Hamilton methodology:

1 Identify and commit investments to ensure that requirements for specific intangible resources and core products are met.

\subsection{A reworked model for innovation strategy formulation}

In revisiting the Booz Allen and Hamilton methodology with a resource-based approach as opposed to a positioning approach several changes of the original methodology have been suggested in the propositions. In the original methodology (illustrated in Figure 1) internal and external scanning, evaluation of portfolios, aligning technology and business, and investment decisions emphasise positions in product-markets and focus on end-products. This approach is more suitable in non-dynamic competitive environments.

Figure 1 The original Booz Allen and Hamilton four-step methodology for innovation strategy formulation

\begin{tabular}{|c|c|c|c|}
\hline $\begin{array}{l}\text { Step 1: } \\
\text { Technology situation } \\
\text { assessment }\end{array}$ & $\begin{array}{l}\text { Step 2: } \\
\text { Technology portfolio } \\
\text { development }\end{array}$ & $\begin{array}{l}\text { Step 3: } \\
\text { Technology and business } \\
\text { strategy integration }\end{array}$ & $\begin{array}{l}\text { Step 4: } \\
\text { Setting technology } \\
\text { investment priorities }\end{array}$ \\
\hline Scan & Evaluate & Align & Invest \\
\hline $\begin{array}{l}\text { - Internal (I) } \\
\text { - External (E) } \\
\text { Relative to... } \\
\end{array}$ & $\begin{array}{l}\text { - Technology importance (TI) } \\
\text { - Relative technology position } \\
\text { (RTP) }\end{array}$ & $\begin{array}{l}\text { - Align technology portfolio with } \\
\text { current business portfolio }\end{array}$ & $\begin{array}{l}\text { - Identify investment } \\
\text { requirements }\end{array}$ \\
\hline $\begin{array}{l}\text { - (I) Specific product and } \\
\text { specific business } \\
\text { - (E) Investment } \\
\text { patterns of competitors }\end{array}$ & $\begin{array}{l}\text { - (TI) Specific business segment } \\
\text { (RTP) Positions compared to } \\
\text { competitors }\end{array}$ & $\begin{array}{l}\text { The needs of the business } \\
\text { strategy }\end{array}$ & $\begin{array}{l}\text { - Each specific product in each } \\
\text { specific product market }\end{array}$ \\
\hline
\end{tabular}

Source: As interpreted from Pappas (1984).

A resource-based approach implies that corporations should strive to keep flexibility in product-markets by focusing on the corporation's resources rather than focusing on positioning in product-markets. The revisited methodology based on a resource-based approach (illustrated in Figure 2) emphasises innovation strategy formulation based on intangible resources and core products in order to gain a competitive advantage. This approach seems to be more suitable in a dynamic environment.

\subsubsection{Summary and response from previous propositions}

Literature on the resource-based view of the firm has exemplified some contexts where the revisited methodology may be more suitable for innovation strategy formulation. The four main contingencies that have become evident from theory are; the nature of the competitive environment, the impact of technological discontinuities, the characteristics of resources used and the number of product-markets served by the corporation. 
In blurring and highly competitive environments, where competitors are numerous and difficult to scan, the revisited methodology is theoretically more suitable as focusing on resources is more stable. As resources are path dependent and slow to change, corporations who are susceptible for discontinuous technological changes should use the revisited methodology. If the nature of the intangible resources possessed by a corporation are such that they can be utilised across a wide variety of product applications the revisited methodology is more useful. If the corporation is active within a large number of product-markets focusing on resources makes it easier to extend intangible resources over multiple markets and also make it easier for the corporation to uncover new product-markets. In these cases, the revisited methodology would be more helpful than the original.

Figure 2 The revisited Booz Allen and Hamilton four-step methodology for innovation strategy formulation

\begin{tabular}{|c|c|c|c|}
\hline $\begin{array}{l}\text { Step 1: } \\
\text { Technology situation } \\
\text { assessment }\end{array}$ & $\begin{array}{l}\text { Step 2: } \\
\text { Technology portfolio } \\
\text { development }\end{array}$ & $\begin{array}{l}\text { Step 3: } \\
\text { Technology and business } \\
\text { strategy integration }\end{array}$ & $\begin{array}{l}\text { Step 4: } \\
\text { Setting technology } \\
\text { investment priorities }\end{array}$ \\
\hline Scan & Evaluate & Align & Invest \\
\hline $\begin{array}{l}\text { - Internal (I) } \\
\text { - External (E) }\end{array}$ & $\begin{array}{l}\text { - Technology importance (TI) } \\
\text { - (RTP) Relative technology } \\
\text { position }\end{array}$ & $\begin{array}{l}\text { - Dynamic interaction between } \\
\text { technology and business } \\
\text { portfolio }\end{array}$ & $\begin{array}{l}\text { - Identify investment } \\
\text { requirements }\end{array}$ \\
\hline $\begin{array}{l}\text { - (I) Resources } \\
\text { - (E) Similarities in resource } \\
\text { composition }\end{array}$ & $\begin{array}{l}\text { - (TI) Specific resources } \\
\text { - (RTP) Core products }\end{array}$ & - Core products & $\begin{array}{l}\text { - For each identified core } \\
\text { product }\end{array}$ \\
\hline
\end{tabular}

Based on the commonly held view of the increasingly dynamic nature of technology and innovation; including increased competition, greater turbulence, shortening life-cycles and increased globalisation (Chiesa, 2001; Teece, 1996), it would seem as if the revisited methodology ought to be better for innovation strategy formulation.

Proposition 8: In the process of innovation strategy formulation, the revisited Booz Allen and Hamilton methodology is more suitable than the original methodology.

\section{Research method and case descriptions}

In exploring a phenomenon such as innovation strategy formulation processes in action and within its real-life context inside the organisation a case based approach is a promising venture - especially since the theoretical propositions state that the internal and environmental contexts affect the phenomenon to be studied (Yin, 2003). Because this study focuses on innovation strategy the R\&D organisation within two firms, Arla Foods and Billerud, were chosen for the case studies. The rationale behind the case selection is further developed in the subsequent section.

The studies were conducted in Sweden over a period of 12 months and are mainly based on semi-structured interviews with informants in top management positions at Arla Foods and Billerud who were all personally involved in innovation strategy formulation. At Arla Foods three informants were located at an R\&D unit in Sweden. At Billerud two informants were interviewed at a Swedish paper mill. As the unit of analysis is the strategy formulation process within the R\&D organisation the data from the interviews have been integrated with further case data collected via annual reports, internal reports and internal strategy documents to avoid relying solely on the opinion of 
individuals (Yin, 2003). The interviews and further data collection were conducted as a team by two investigators who kept separate case protocols. Final analysis, as well as data collection, was conducted with the theoretical propositions as orientation. This means that the focus of the analysis has been on the steps of the strategy formulation process and the contingencies suggested by theory. By iterating between theory and data, that is, returning to the cases to find more information on specific issues and contingencies, we believe that we have reached the theoretical saturation advocated by Eisenhardt (1989). Finally, as suggested by Yin (2003), individual case reports were prepared and sent to the informant for validation to support the reliability of the case findings.

\subsection{Case descriptions}

In order to explore the contextual variables in greater depth and conduct cross-case analysis two cases were selected for this study, Arla Foods and Billerud. They were selected on several bases:

1 Both corporations are part of the process industry - Arla Foods is in the food and beverage sector and Billerud is in the pulp and paper sector. That the production process is centred around raw materials also means that they share several fundamental characteristics in R\&D as well (Barnett and Clark, 1996; Dennis and Meredith, 2000).

2 Though they may be defined as low-tech, both firms rely heavily on their R\&D organisation to bring new products to market and improve manufacturing processes. Furthermore, both corporations' $R \& D$ intensity is comparable to each other and to their respective industry averages $(0.8 \%$ for the food and beverage industry and $0.7 \%$ for the pulp and paper industry (Lager 2002)).

3 Both corporations are multinationals as they conduct R\&D and have production plants in more than one country and sales offices in more than ten countries.

4 It was determined that except for shared characteristics from being multinational process industry firms Arla Foods and Billerud were different in respect to the nature of their competitive environment, type and number of products and customers and type of technologies used. This allows for making comparisons on the contingencies revealed by the propositions.

\subsubsection{Arla Foods}

Arla Foods is Europe's largest dairy corporation with a turnover of USD 6.4 billion and 21,000 employees, with its own production plants in eight countries and sales offices in 23 countries. It produces and markets branded products to end customers as well as supplying milk-based ingredients to industrial food producers. Hence, it sells both fast-moving consumer products (such as fresh milk, yoghurt, creams, cooking products, cheese, butter and spreads) and commodity products (such as retail packed milk powder, sweeteners and milk proteins). The industrial customers include corporations from a variety of industries, such as nutrition, dairy, meat, beverage, ice cream and pharmaceutical. While Arla Food's portfolios of businesses are unrelated in terms of customers, distribution channels and merchandising, this multidivisional and diversified corporation is glued together by the use of the same raw material for almost 
all its products, viz. milk. Depending on product-market and industry characteristics Arla Foods uses dual generic competitive strategies, both differentiation and cost leadership.

Arla Foods has an R\&D intensity of $0.5-0.6 \%$ and conducts $R \& D$ at three innovation centres. Development takes place in project teams comprising staff from production, marketing and innovation, whereas basic research is often carried out in conjunction with universities or other external research institutes. Of the internal R\&D, about $90 \%$ is carried out in conjunction with marketing and about $10 \%$ is carried out in conjunction with production. The three innovation centres are involved in an annual centralised work process of innovation strategy formulation. In all, the innovation centres develop more than 200 new products each year.

\subsubsection{Billerud}

Billerud is a pulp and paper corporation with a sales turnover of around USD 1.0 billion that employs 2600 people. It has production plants in two countries and sales offices in 11 countries. Billerud is a niche player in a large and diverse industry, focusing primarily on two packaging paper segments: kraft paper and containerboard. Hence, Billerud uses differentiation focus as its generic competitive strategy. Billerud does not convert pulp into consumer products (finished products): its customers are exclusively manufacturers of paper-based packaging.

The main focus of Billerud's R\&D is to enhance product quality and to generate substantially new products. The R\&D intensity is about $0.7 \%$ and the corporation develops 3-5 new products each year. There are no centralised R\&D departments, so each production plant conducts its own $R \& D$. The process of innovation strategy formulation is also mainly decentralised. Top management advises on product development concerns, whereas process development concerns are treated more or less in isolation at each production plant.

\section{Findings from the case studies}

Proposition 1: In the process of innovation strategy formulation, it is more appropriate to base the internal scan on intangible resources than basing it with respect to each specific product or each specific business segment.

Arla Foods supports an internal scan based on a corporate-wide set of intangible resources. A scan based on each specific product or each specific business is considered nearly impossible for such a highly diversified corporation due the vast amount of information it would be necessary to process about different products and markets. A centralised process of innovation strategy formulation is unfit to handle the extensive amount of information that is necessary when competing in many product-markets but works fine when scanning on the level of intangible resources. The, in many cases, short product-life cycles also make it difficult to conduct scanning based on products.

Billerud, on the other hand, supports an internal scan based on each specific end product or each specific business. Billerud formulates separate innovation strategies for each paper-mill, which makes it difficult to assess the complete set of intangible resources for the corporation as a whole. In addition, because Billerud uses a differentiation focus strategy, they have fewer products to scan. 
Proposition 2: In the process of innovation strategy formulation, it is more appropriate to focus the external scan on corporations with similarities in intangible resources than focusing on investment patterns of immediate competitors in each product-market.

Arla Foods supports an external scan based on similarities in intangible resources. Arla Foods' competitive environment is characterised by blurring industry boundaries, ever-changing customer preferences with frequent horizontal moves in the value chains (e.g. retailers introducing own labels and producing milk-based products), with often unidentifiable competitors as a result. Intangible resources, often originating from $\mathrm{R} \& \mathrm{D}$, are considered the best competitive weapon available; therefore, it is important to scan for potential competitors who show similarities in intangible resources.

Billerud supports an external scan based on investment patterns of immediate competitors in each product-market. Billerud's competitive environment is characterised by clear industry boundaries, with competitors easily identifiable. In addition, Billerud uses a differentiation focus strategy, primarily focusing on just two segments of the packaging industry (kraft paper and containerboard), making the competitive environment perspicuous.

Proposition 3: In the process of innovation strategy formulation it is more appropriate to evaluate the technology importance with respect to core products than to evaluate technology importance with respect to each given business segment.

Arla Foods supports evaluation of technology importance with respect to intangible resources for core product. As Arla Foods develops more than 200 new products annually, for numerous business segments, it chooses to evaluate technology importance with respect to a total of seven identified 'focus areas' (e.g. shelf-life, health and packaging). These focus areas make up the foundation of necessary intangible resources for most business segments.

Billerud supports evaluation of technology importance with respect to each business segment because it competes in very few business segments. Hence, it is possible to immediately determine technology importance with respect to each business segment.

Proposition 4: In the process of innovation strategy formulation, it is more appropriate to evaluate the relative technology position in respect to core products rather than to evaluate relative technology position with respect to each identified business segment.

Arla Foods supports evaluation of the technology portfolio with respect to relative technology position in each identified business segment. It uses a competence-gap analysis to determine its technology position in each business segment. As one R\&D manager at Arla Foods said: "As it ultimately is about conquering a business segment with end products, there is no reward in finishing second; therefore, we have to know what we are up against and where we stand in terms of technology in each business segment".

Billerud supports evaluation of the technology portfolio with respect to relative technology position in each identified business segment with the same basic arguments as in Proposition 3, that is, that there is no need for core products because of the low degree of diversity in both business segments and technology.

Proposition 5: In the process of innovation strategy formulation, the relationship between technology and business strategy should be characterised by a dynamic relationship rather than a static relationship. 
Arla Foods supports the notion that there is a dynamic relationship between technology and business strategy. At Arla Foods the work processes of both innovation strategy formulation and business strategy formulation are centralised. Both strategy processes are run simultaneously and therefore facilitate a dynamic relationship. The role of R\&D is to drive innovation strategy to make it easier for Arla Foods to conceptualise new products and to enter new markets.

Billerud supports the notion of more a static relationship between technology and business strategy and stresses that the innovation strategy should respond to the needs of the business strategy. Business strategy formulation is centralised and conducted at corporate headquarters whereas innovation strategy formulation is decentralised and conducted at each paper-mill. Business demands drive innovation strategy in such a way that R\&D delivers technical solutions for product requirements. Corporate headquarters also advises on product development concerns, which is used as input to each paper-mill's process of innovation strategy formulation.

Proposition 6: In the process of innovation strategy formulation, it is appropriate to commit investments to ensure that requirements for specific intangible resources are met rather than to ensure that investments are committed to each specific business.

Arla Foods considers it is more appropriate to commit investments to ensure competence requirements for specific core products. Each of its seven focus areas contains intangible resources which are the bases for corporate-wide product development. The investments in focus areas are conducted with the use of 'strategic buckets' (Cooper et al., 1998) to ensure that intangible resource investments in different focus areas do not compete with each other.

Billerud considers it more appropriate to ensure that resources are committed to each specific business with the basic arguments that the low degree of diversity in both business segments and technology does not entail investments in intangible resources used for a broad range of products.

Proposition 7: In the process of innovation strategy formulation, it is appropriate to commit investments to ensure that requirements for specific core products are met rather than to ensure that investments are committed to specific products.

Arla Foods supports committing investments to specific core products. The need for specific products is not dealt with directly in the work process of innovation strategy formulation, but rather it is up to the innovation centre to create a wellspring of knowledge from which the diversified business units can drink when needed. However, the main goal is not just investing for current product application, but building intangible resources and core products that can be applied in future uses.

Billerud supports committing investments to each specific product with the same basic arguments as in Propositions 3, 4 and 6, that is, that there is no need for core products because of the low degree of diversity in both business segments and technology. In an industry where production alterations imply heavy investments and require extensive lead-time for implementation, any move by competitors will require development time and therefore make countermoves possible for industry incumbents.

Proposition 8: In the process of innovation strategy formulation, the revisited Booz Allen and Hamilton methodology is more suitable than the original methodology. 
Arla Foods supports the revisited methodology for innovation strategy formulation.

Billerud supports the traditional methodology for innovation strategy formulation.

Table 1 summarises the findings of propositions in the case studies. The findings show that Arla Foods supports the revisited, resource-based, Booz Allen and Hamilton methodology, whereas Billerud supports the original, positioning-oriented, Booz Allen and Hamilton methodology. It is clearly showed that that both multinational corporations are consistent in using either a resource-based or a positioning approach to innovation strategy formulation.

Table 1 Summary of the findings with respect to each proposition

\begin{tabular}{lcc}
\hline Proposition & Arla Foods & Billerud \\
\hline 1 - Internal scan & B & A \\
2 - External scan & B & A \\
3 - Tech. importance & B & A \\
$4-$ Relative tech. importance & A & A \\
5 - Aligning strategies & B & A \\
6 - Invest in resources & B & A \\
$7-$ Invest in core products & B & A \\
$8-$ Revisited methodology & B & A \\
\hline
\end{tabular}

Note: $\mathrm{A}=$ Original Booz Allen and Hamilton methodology based on a positioning approach to strategy; B = Revisited Booz Allen and Hamilton methodology based on a resource-based approach to strategy.

\section{Discussion of the results}

The case studies indicate that there seem to be several contextual grounds for either adhering to the original Booz Allen and Hamilton methodology or following the reasoning of the revisited methodology. Three overarching contingencies have been identified; the level of diversification; the characteristics of industry boundaries, customers and competitors and the role and organisation of R\&D.

\subsection{Level of diversification}

The case-findings illustrate that the level of diversification is an important factor in deciding on an innovation strategy methodology. The level of diversification can be analysed from two main points of view (Chiesa and Manzini, 1997); either from an external perspective, which focuses on the product-markets and industries entered, the products offered and the customers and geographical area served or an internal perspective which focuses on the relationships between diversification and tangible and intangible resources.

In the case of Arla Foods' external perspective it can be considered highly diversified as in terms of product-markets served, as it sells both fast-moving consumer products (such as fresh milk, yoghurt, cream, cooking products, cheese, butter and spreads) and commodity products (such as retail packed milk powder, sweeteners and milk proteins) to industrial customers in a variety of industries (such as nutrition, dairy, meat, beverage, 
ice cream and pharmaceuticals) spread out geographically all over the world. However, internally, Arla Foods is highly focused on a few central focus areas (e.g. core products and intangible resources) which are valuable in a many product-markets. Hence, the sheer number of end-products and different product-markets suggests that Arla Foods cannot support a positioning approach. Assessing each product and product-market in terms of positions would be too time-consuming, especially in the light of some cases of extremely short product life-cycles.

Externally, Billerud is competing in a few product-markets, with few product offerings, and has only one type of customers, manufacturers of paper-based packaging, while $81 \%$ of sales are made within Europe. Internally, Billerud has a somewhat consistent collection of intangible resources in R\&D. Hence, in terms level of diversification, Billerud seem to have the option to either focus on positions or resources in the process of innovation strategy formulation.

\subsection{Characteristics of industry boundaries, customers and competitors}

The characteristics of the environment was suggested by the resource-based approach as being an important reasoning for switching perspective from positions to resources. In a positioning approach to strategy, it is assumed that each product-market is distinct, hence, customers and competitors are identifiable and competition occurs at the level of product lines and/or businesses (Sissors, 1966). However, these assumptions are not valid in the case of Arla Foods. As an example, Arla Foods experiences blurring industry boundaries as retailers introduce their own labels and produce their own milk-based products. Hence, backward integration (Porter, 1985) is used by retailers to get around intermediate producers, such as Arla Foods, while at the same time integrating forward to reach end customers through retail-owned-brands. As a fact, industry boundaries are blurring as former customers are becoming competitors.

On the other hand, the case of Billerud does not experience the same turbulent competitive environment. Hence, the underlying assumptions made in a positioning approach, still hold in the corporate context of Billerud and are, therefore still, a solid starting point for strategy formulation. In the case of Billerud, the perceptions of quality constantly changes for Billerud's customers and therefore gradually demand more complex products. This has got to do with trends in packaging of consumer products (such as coated paper for carrier bags and fashion bags). Arla Foods introduces about 200 new products each year while competitors and customers remain, more or less, ambiguous. Hence, Arla Foods competitive environment, is characterised by weakly defined industry boundaries and where competition is mostly played our on the ability to generate new products or market combinations.

\subsection{The role and organisation of $R \& D$}

In the case of Arla Foods, innovation is seen as a powerful competitive weapon which can influence business and corporate strategies. As both the work-process of innovation strategy formulation and the R\&D function are centralised while the competitive environment is turbulent, a dynamic interaction between innovation and business strategies is encouraged by top management. As Arla Foods develops about 200 new products each year, it is not possible to evaluate each specific product development project with respect to the business portfolio. Furthermore, as intangible resources 
change more slowly than projects or product lines, evident in the case of Arla Foods, it must be extremely difficult and time consuming, to capture an attractive relative position in a product-market without having the suitable intangible resources already available as the competitive environment is turbulent. Instead, R\&D is used as a wellspring of knowledge for the business portfolio to capitalise on and be driven by. This is one reason for why Arla Foods supports a dynamic interaction between innovation and business strategy. Billerud, on the other hand, uses several decentralised work-processes of innovation strategy formulation, conducted at each paper-mill, while the work-process of business strategy formulation is centralised and conducted at corporate headquarter. Hence, in the case of Billerud, $R \& D$ responds to the needs of the business portfolio in terms of product development and to the needs of each paper-mill in terms of process development. The alignment between business and technology strategy is therefore more commonly centred on the demands of business strategy.

In summary, the role and organisation of R\&D, along with the other two identified contingencies, seem to heavily influence if positions or resources is the basis in innovation strategy formulation.

\section{Conclusions and further research}

Not much research had focused on tools that firms actually use on a day-to-day basis. Tools have become the domain of management consultants. However, studying these tools is one way of getting closer to what firms actually do. While practitioners are in need of management tools and techniques that can help them structure problems and aid in decision making, this paper shows that a resource-based approach to innovation strategy formulation can useful in an appropriate setting. The revisited Booz Allen and Hamilton methodology shows that while firmly grounded in the resource-based approach, corporations will still benefit in explicitly taking into consideration the competitive environment. We have found evidence to suggest that when a corporation's competitive environment becomes too complex to predict and the product-markets become too many to survey, it would seem logical to retreat into the world of resources.

The case study also shows that both the revisited methodology, based on a resource-based approach to strategy and the traditional methodology, based on a positioning approach to strategy, are used in corporations today. In addition, it shows that a corporation focuses almost exclusively on either resources or positions in the process of innovation strategy formulation; hence, a mixture of the two approaches does not exist in this study. However, this does not automatically imply that the possibility of hybrids existing is excluded.

It is indicated that the choice between the methodologies is affected by three key aspects

1 the level of diversification

2 the characteristics of industry boundaries, customers, competitors and

3 the role and organisation of $R \& D$.

In that sense, this paper highlights the importance of adjusting to the internal context as well as the external context when choosing a suitable methodology for innovation strategy formulation. The question is not whether focusing on resources or positions is 
universally better; rather this study shows that it is dependent on the internal and external context. Hence, both approaches are equally useful, depending on the contingencies presented by this study.

It is worth mentioning that the two methodologies presented in this paper are not intended to function as the sole basis for innovation strategy formulation. Instead, they can be used as an overarching framework and as a starting-point for discussion.

\subsection{Limitations and further research}

The goal of this study has been to expand and generalise theory from propositions on strategy formulation processes. The limitations of case studies, especially the difficulties of making scientific generalisations from case results, imply that replications of the study will provide valuable additional knowledge on strategy formulation processes. Further work either deepening the existing cases or expanding the study to include complementary case firms may yield additional contingencies or more knowledge on the contingencies previously described. The contingencies found in this study may also be confirmed in quantitative studies.

The process industry is considered a mature industry. It is possible that newer and more dynamic industries will provide different contingencies. Exploring the two models of strategy formulation across industries may lead to the discovery of other contingencies. Also it is possible that as resource configurations (financial, physical, incremental, etc.) that firms use differ across firms and industries so will the formulation processes.

At the end of the day, researchers and managers want to know how all this relates to performance - or simply: which firms fare better? While theory suggests that there must be a fit between strategy formulation process and context this relation should be explored further.

In conclusion, any additional studies, whether they are deepening case studies of quantitative investigations, should focus more on performance as a dependent variable.

\section{Managerial implications}

As practitioners are in the need of normative and hands-on management guidelines, the aim of this section is to provide practical guidance. In this paper, a revisited methodology for innovation strategy formulation is presented and three contingencies are identified. These three contingencies are important for practitioners to take into consideration when choosing between a positioning or resource-based approach to the Booz Allen and Hamilton methodology. Evidence show that there is a clear need for adopting an approach consistent with the corporate internal context and competitive environment. Firstly, it is indicated that level of internal and external diversification influences appropriate approach. Hence, if a corporation is present in many product-markets, with a wide range of customers, wide geographical coverage and have a compact bundle of resources it adheres to the revisited, resource-based, methodology. A positioning approach is favoured if a corporation is present in only a few product-markets, with a limited set of customers. Secondly, if a corporation experiences a turbulent competitive environment with blurring industry boundaries as customers, competitors are hard to identifiable while horizontal and vertical activity in the value chain is volatile; the 
corporation seems to adhere to the revisited methodology. A positioning approach is favoured when the corporation is active in a less dynamic environment. Finally, a resource-based approach to innovation strategy formulation is favoured when the corporation expects R\&D to drive business strategy. On the contrary, a positioning approach is favoured when $R \& D$ is more often driven by business strategy.

The three contingencies and the most appropriate methodology for innovation strategy formulation are summarised in Figure 3 below. The original and revisited methodology along with the illustration provided below can be used for communicative purposes among managers from market-oriented functions, such as sales and marketing and technology-oriented functions, such as R\&D and production. Where many management tools of today are very detailed and multifaceted, which makes them difficult to implement, the straightforward nature of the original and revisited Booz Allen and Hamilton methodology implies that they can be used as a first step towards a more detailed and structured approach to innovation strategy formulation.

Figure 3 Two approaches to innovation strategy formulation and when to use which

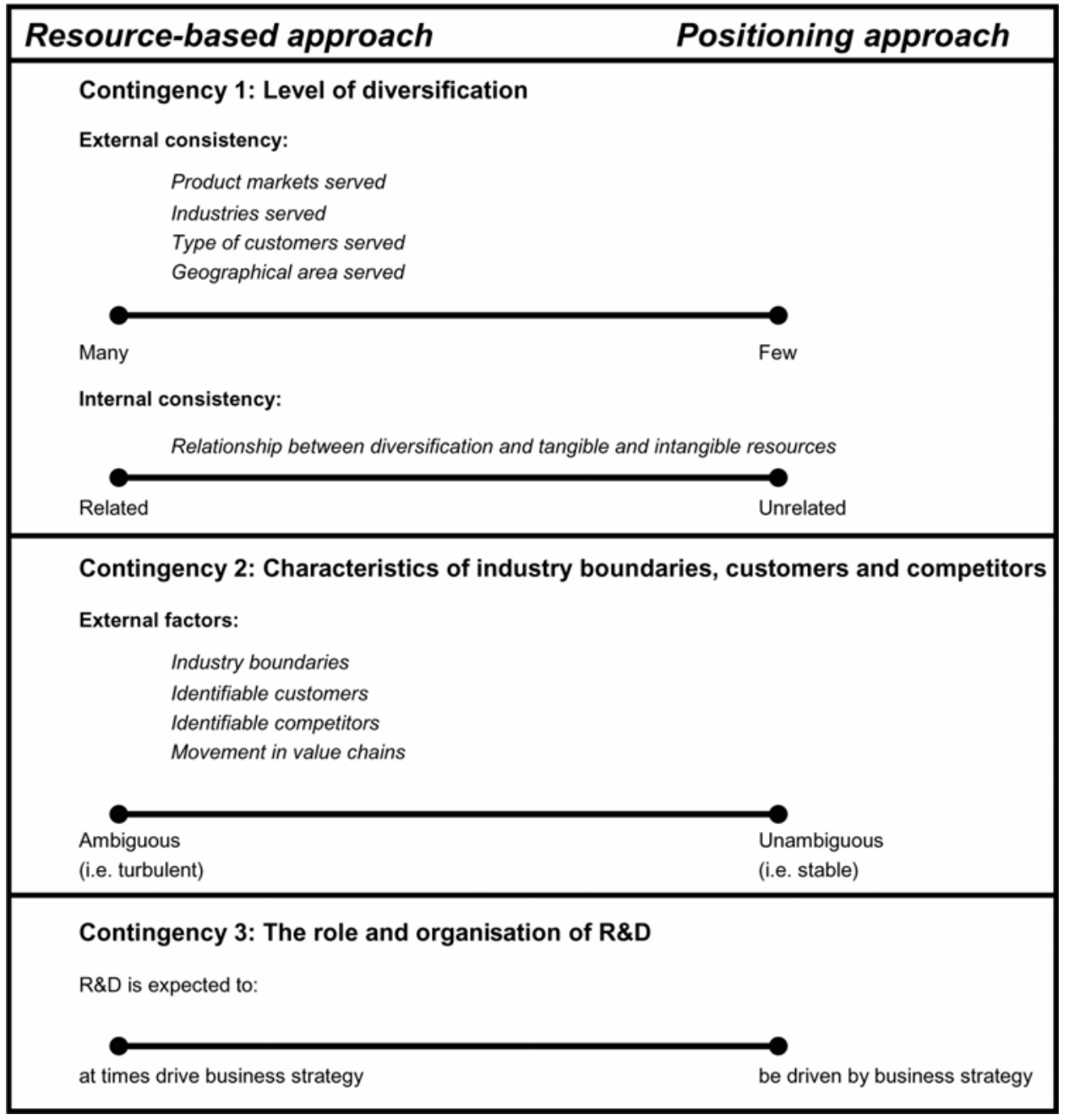




\section{Acknowledgements}

This work has been financed by the Kempe Foundations and Jan Wallander's and Tom Hedelius' Foundation; their financial support is gratefully acknowledged. The authors also wish to express their sincere appreciation to Henrich R. Greve and Torben J. Andersen for their insightful comments and Thomas Lager for valuable assistance.

\section{References}

Anderson, P. and Tushman, M.L. (1990) 'Technological discontinuities and dominant designs: a cyclical model of technological change', Administrative Science Quarterly, Vol. 35, No. 4, pp.604-633.

Bain, J.S. (1956) Barriers to New Competition: Their Character and Consequences in Manufacturing Industries, Cambridge, MA.

Bain, J.S. (1968) Industrial Organization, New York: Wiley.

Barnett, B.D. and Clark, K.B. (1996) 'Technological newness: an empirical study in the process industries', Journal of Engineering and Technological Management, Vol. 13, No. 3, pp.263-282.

Barney, J.B. (1991) 'Firm resources and sustained competitive advantage', Journal of Management, Vol. 17, pp.99-120.

Bettis, R.A. and Hitt, M.A. (1995) 'The new competitive landscape', Strategic Management Journal, Vol. 16, No. 5, pp.7-20.

Chandler, A.D. (1962) Strategy and Structure: Chapters in the History of the Industrial Enterprise, Cambridge: MIT Press.

Chiesa, V. (2001) R\&D Strategy and Organisation: Managing Technical Change in Dynamic Contexts, London: Imperial College Press.

Chiesa, V. and Manzini, R. (1996) 'Competence levels within firms: a static and dynamic analysis', in A. Heene and R. Sanchez (Eds). Competence-Based Strategic Management, Chichester, UK: John-Wiley and Sons.

Chiesa, V. and Manzini, R. (1997) 'Competence-based diversification', Long Range Planning, Vol. 30, No. 2, pp.209-218.

Christensen, C.M. (1997) The Innovator's Dilemma: When New Technologies Cause Great Firms to Fail, Cambridge: Harvard Business School Press.

Collis, D. (1994) 'Research note: How valuable are organizational capabilities?' Strategic Management Journal, Vol. 15, No. 2, pp.143-152.

Cooper, R.G., et al. (1998) Portfolio Management for New Products, Reading, MA: Perseus Books.

Danneels, E. (2002) 'The dynamics of product innovation and firm competences', Strategic Management Journal, Vol. 23, No. 12, pp.1095-1121.

D'Aveni, R.A. (1995) Hypercompetitive Rivalries: Competing in Highly Dynamic Environments (with Robert Gunther), New York: Free Press.

De Toni, A. and Tonchia, S. (2002) 'Strategic planning and firms' competencies: traditional approaches and new perpectives', International Journal of Operations and Production Management, Vol. 23, No. 9, pp.947-976.

Dennis, D. and Meredith, J. (2000) 'An empirical analysis of process industry transformation systems', Management Science, Vol. 46, No. 8, pp.1085-1099.

Eisenhardt, K.M. (1989) 'Building theories from case study research', Academy of Management Review, Vol. 14, No. 4, pp.532-550. 
Eisenhardt, K.M. and Martin, J.A. (2000) 'Dynamic capabilities: what are they?' Strategic Management Journal, Vol. 21 (Special Issue: The Evolution of Firm Capabilities), pp.1105-1121.

Foss, N.J. (1998) 'The resource-based perspective: an assessment and diagnosis of problems', Scandinavian Journal of Management, Vol. 14, No. 3, pp.133-149.

Grant, R.M. (1991) 'The resource-based theory of competitive advantage: implications for strategy formulation', California Management Review, Vol. 33, No. 3, pp.114-135.

Haanes, K. and Löwendahl, B. (1997) 'The unit of activity: towards an alternative to the theories of the firm', in H. Thomas, D. O'Neal and M. Ghertman (Eds). Strategy Structure and Style, Chichester, UK: John Wiley and Sons, pp.201-218.

Helfat, C.E. (1994) 'Evolutionary trajectories in petroleum firm R\&D', Management Science, Vol. 40, No. 12, pp.1720-1747.

Hitt, M.A. and Ireland, R.D. (1985) 'Corporate distinctive competence, strategy, industry and performance', Strategic Management Journal, Vol. 6, No. 3, pp.273-293.

Hofer, C.W. and Schendel, D. (1978) Strategy Formulation: Analytical Concepts, St. Paul, MN: West Publishing Co.

Itami, H. and Numagami, T. (1992) 'Dynamic interaction between strategy and technology', Strategic Management Journal, Vol. 13 (Special Issue: Fundamental Themes in Strategy Process Research), pp.119-135.

Knott, A.M. (2003) 'The organizational routines factor market paradox', Strategic Management Journal, No. 24, p.10.

Larsson, A. and Bergfors, M. (2006) 'Heads or tails in innovation strategy formulation? Porterian or Penrosian, let context determine', International Journal of Process Management and Benchmarking, Vol. 1, No. 4, pp.297-313.

Lager, T. (2002) 'Product and process development intensity in process industry: a conceptual and empirical analysis of the allocation of company resources for the development of process technology', International Journal of Innovation Management, Vol. 6, No. 2, pp.105-130.

Leonard-Barton, D. (1992) 'Core capabilities and core rigidities: a paradox in managing new product development', Strategic Management Journal, Vol. 13 (Special Issue: Strategy Process: Managing Corporate Self-renewal), pp.111-125.

Leonard-Barton, D. (1995) Wellsprings of Knowledge: Building and Sustaining the Sources of Innovation, Boston, MA: Harvard Business School Press.

Little, B. (1984) 'From the editor', Journal of Product Innovation Management, Vol. 1, No. 1, pp. $3-4$.

Markides, C.C. and Williamson, P.J. (1994) 'Related diversification, core competencies and corporate performance', Strategic Management Journal, Vol. 15, (Special Issue: Strategy: Search for New Paradigms), pp.149-165.

Mason, E.S. (1939) 'Price and production policies of large-scale enterprise', American Economic Review, Vol. 39, No. 1.

Mason, E.S. (1949) 'The current state of the monopoly problem in the US', Harvard Law Review, Vol. 62, pp.1265-1285.

Meyer, M.H. and Utterback, J.M. (1993) 'The product family and the dynamics of core capability', Sloan Management Review, Vol. 34, No. 3, pp.29-47.

Miller, W.L. and Morris, L. (1998) Fourth Generation R\&D: Managing Knowledge, Technology and Innovation, New York: John Wiley \& Sons, Inc.

Pappas, C. (1984) 'Strategic management of technology', Journal of Product Innovation Management, Vol. 1, No. 1, pp.30-35.

Penrose, E.T. (1959) The Theory of the Growth of the Firm, Oxford: Basil Blackwell.

Porter, M.E (1980) Competitive Strategy: Techniques for Analyzing Industries and Competitors, New York: Free Press. 
Porter, M.E. (1985) Competitive Advantage: Creating and Sustaining Superior Performance, New York: Free Press.

Prahalad, C.K. (1998) 'Managing discontinuities: the emerging challenge', Research Technology Management, Vol. 41, No. 3, pp.14-23.

Prahalad, C.K. and Hamel, G. (1990) 'The core competence of the corporation', Harvard Business Review, Vol. 68, No. 3, pp.79-91.

Roussel, P.A., et al. (1991) Third Generation R\&D: Managing the Link to Corporate Strategy, Boston, MA: Harvard Business School Press.

Rumelt, R.P. (1984) 'Towards a strategic theory of the firm', in R.B. Lamb (Ed). Competitive Strategic Management, Englewood Cliffs, NJ: Prentice-Hall, pp.556-570.

Sanchez, R. (1995) 'Strategic flexibility in product competition', Strategic Management Journal, Vol. 16 (Special Issue: Technological Transformation and the New Competitive Landscape), pp.135-159.

Selznick, P. (1957) Leadership in Administration: A Sociological Perspective, New York: Harper and Row.

Sissors, J.Z. (1966) ‘What Is a Market?’ Journal of Marketing, Vol. 30, No. 3, pp.17-21.

Snow, C.C. and Hrebiniak, L.G. (1980) 'Strategy, distinctive competence, and organizational performance', Administrative Science Quarterly, Vol. 25, No. 2, pp.317-336.

Teece, D. (1996) 'Firm organization, industrial structure, and technological innovation', Journal of Economic Behavior and Organization, Vol. 31, pp.193-224.

Teece, D.J., et al. (1997) 'Dynamic capabilities and strategic management', Strategic Management Journal, Vol. 18, No. 7, pp.509-533.

Tushman, M. and Anderson, P.C. (1986) 'Technological discontinuities and organizational environments', Administrative Science Quarterly, Vol. 31, No. 3, pp.439-465.

Utterback, J.M. (1994) Mastering the Dynamics of Innovation: How Companies can Seize Opportunities in the Face of Technological Change, Boston, MA: Harvard Business School Press.

Wernerfelt, B. (1984) 'A resource-based view of the firm', Strategic Management Journal, Vol. 5, No. 2, pp.171-180.

Winter, S.G. (1987) 'Knowledge and competence as strategic assets', in D. Teece (Ed). The Competitive Challenge, Harper \& Row, pp.159-184.

Yin, R.K. (2003) Case Study Research: Design and Methods, Thousand Oaks, CA: Sage Publications.

\section{Note}

${ }^{1}$ By this classification, various concepts such as core competence (Leonard-Barton, 1992; Prahalad and Hamel, 1990), capabilities (Grant, 1991), distinctive competence (Hitt and Ireland, 1985; Selznick, 1957; Snow and Hrebiniak, 1980), dynamic capabilities (Eisenhardt and Martin, 2000; Teece et al., 1997), strategic assets (Winter, 1987), resource deployment (Hofer and Schendel, 1978), to name a few, are all part of the broader categories of intangible and/or tangible resources. For the purpose of this paper however, we need not concern ourselves with the debate within these concepts (Foss, 1998), but will simply focus on the basic premises of the resource-based approach. 